\title{
9. Constitution-making in a stifled democracy: A case study of self-censorship perpetuating propaganda in Fiji
}

\section{ABSTRACI}

Fiji is preparing for general elections in 2014 by which time the country will have been under military rule for eight years. A process of constitutionmaking began in mid-2012 and a new constitution should be available by 2013. Citizens and the media continue to practise self-censorship and the military regime continues to remind citizens that it would crack down harshly on 'trouble-makers'. In the same breath, the regime has promised the international community that the process for constitution-making will be free, fair, participatory and transparent. This article, through analysis of media reporting, will examine whether current self-censorship by media is aiding the constitution-making process, and if indeed, self-censorship is promoting peace? Through an analysis of the work of the Constitution Commission, the article will analyse the extent of participation of citizens in the context of a stifled democracy.

Keywords: censorship, democracy, governance, media freedom, selfcensorship, transparency

\section{MOSMI BHIM}

Fiji National University, Suva

\footnotetext{
FTER the abrogation of the 1997 Constitution on 10 April 2009 and being sworn in again, Prime Minister Commodore Voreqe Baini1 marama informed the world of his roadmap - that Fiji will have a new constitution in 2013 that will scrap the ethnic-based electoral system (BBC News, 1 July 2009). He informed the world that the new constitution will be non-racist, and that free and fair elections will be held by 2014 . The
} 
constitution-making process that commenced in July 2012 showed that the plans were on track with the Roadmap to Democracy unveiled by Bainimarama. Chaired by internationally-regarded constitutional expert Professor Yash Ghai, a former UN Rapporteur in Cambodia who helped prepare 15 constitutions, including the new constitutions of Nepal and of his homeland Kenya, the plans ushered in a breath of hope for Fiji. Citizens clamoured to take advantage of this opportunity to express their view of what they desire for a happy and prosperous Fiji.

\section{Freedom vs control}

The constitution process showed two forces at work. Firstly, freedom-Professor Yash Ghai represented freedom and he and his commission kept doing all in their power to encourage Fiji citizens of all walks of life and ages to come forward and share their views and concerns whether in oral, written, or other creative form. The second force, control, was represented by Bainimarama through his numerous threats to the commission chair and individuals and the decrees and statements by the regime's key actors, including the Attorney-General, President, and Permanent Secretary for Information.

In this article, I will try to analyse the process of constitution-making in a situation where most media have been engaging in self-censorship after the April 2009 events and promulgation of the Media Industry Development Decree 2010 (Media Decree) in June. Currently, a draft constitution is awaiting the formation of a Constituent Assembly for deliberation, therefore my analysis will only refer to the period of the creation of the draft constitution.

\section{Context of the review process}

The review process occurred in the context of restrictive laws (Bhim, 2011, p. 1-12). After the abrogation of the constitution on 10 April 2009, restrictive laws were promulgated by the President to curtail the judiciary, and freedom of expression and assembly. The Administration of Justice Decree 2009 promulgated on 16 April gave powers to the President to make all judicial appointments and also automatically terminate any proceedings which challenge any government decisions made between 5 December 2006 and 9 April 2009. The courts do not have jurisdiction to consider any challenges to the abrogation of the 1997 Constitution or any challenges to the decrees promulgated after 10 April 2009. Further decrees were promulgated 
to restrict the rights and independence of civil servants and trade unions and to remove the powers of the Human Rights Commission to challenge the government. Then the Legal Practitioners Decree was promulgated to place all legal practitioners under tight control by vesting the power to issue, cancel or suspend certificates to practice to the Registrar (an appointee of the regime), and the establishment of an Independent Legal Services Commission which has the power to fine guilty people up to $\$ 500,000$, sentence up to five years, suspend licences and close down legal practices.

A Public Emergency Regulations (PER) Decree promulgated on 10 April 2009 had assumed a state of emergency existed in Fiji because elements planning to destabilise the government might exist. The decree curtailed key civil and political rights including freedom of expression and assembly and extended the powers of the military and police officers to enter and search premises, permit and terminate meetings, and to arrest and detain people. It also gave powers to the police to enter newsrooms and censor all news items under the directive of the Permanent Secretary for Information. The PER was lifted in January 2012 in the lead-up to the constitution-making process. However, a new Public Order Decree 2012 was imposed under which all restrictions imposed under the PER were retained and the powers to arrest and detain people were increased. The only restriction not carried forward from the PER was media censorship.

Since the 5 December 2006 coup, Bainimarama has had an antagonistic relationship with journalists laced with threats, intimidations and warnings. After the 2009 abrogation, journalists were detained by police for writing stories the regime did not like. There was a history of deportations, detentions, and changing of newsroom hierarchy. In November 2009, the Regulation of National Spectrum Decree 2009 was promulgated under which all powers to issue or revoke licences became vested in the Attorney-General, Aiyaz SayedKhaiyum; the decision cannot be challenged in any court and breaches can incur a fine of up to $\$ 100,000$ or five years' imprisonment.

The June 2010 Media Decree provided for the establishment of the Media Industry Development Authority of Fiji to regulate and oversee the operations of media organisations and to refer complaints to the media tribunal established under the decree. It imposes stringent requirements to regulate all aspects of reporting, editing and publishing, as well as ownership and investment criteria. Misdemeanours under the decree can incur fines from $\$ 10,000$ to 
$\$ 100,000$ and/or imprisonment of up to two years. The requirement of having 90 percent ownership by permanently residing Fiji citizens forced the sale in September that year, of the 142-year-old newspaper company Fiji Times - then a wholly-owned subsidiary company of Rupert Murdoch's Sydney-based News Limited - to the local Motibhai Group (The Australian, 15 September 2010). A few months later, its owner, Mahendra Motibhai Patel was sentenced to 12 months imprisonment on 14 April 2011 on abuse of office charges related to a Post Fiji Limited wall clock controversy (Fijilive, 14 April 2011).

Several court cases have been lodged by the regime against two news organisations in particular - The Fiji Times and Fiji One Television. Pressure from the regime forced Fiji One Television to strip Anish Chand of the news editor position and give it to fellow journalist Geoffrey Smith. Fiji One's licence expired after 12 years in 2012, however, the government only gave it a six-month licence renewal which was likened to a 'good behaviour bond' by Fiji non-government organisations (NGOs) (Scoop Media, 10 August 2012). Furthermore, The Fiji Times' long-time news editor Netani Rika was forced to resign from his position in October 2010 after the enforcement of the decree and deputy editor Sophie Foster resigned as well after a month's leave (FBC/ PMC, 13 November 2010). The decree came more than a year after the deportation of Fiji Times publisher and acting chief executive Rex Gardner in January 2009 despite being discharged by the court on contempt of court charges (Fiji Times, 27 January 2009). In the preceding year, Fiji Times publisher Evan Hannah and Fiji Sun publisher Russell Hunter had also been deported. Gardner's deportation was announced a few days after the Fiji Times Limited was fined $\$ 100,000$ for contempt of court and editor-in-chief Rika sentenced to three months in jail suspended for two years (ibid). Furthermore, on 26 November 2012, the High Court found The Fiji Times, its publisher and editor-in-chief Fred Wesley guilty of contempt of court and state lawyers recommended an exorbitant fine of $\$ 500,000$ and jail terms (Fiji Times, 27 November 2012). In the judgment delivered on 20 February 2013, The Fiji Times was ordered to pay a $\$ 300,000$ fine, former publisher Brian O'Flaherty was fined $\$ 10,000$, Wesley was sentenced to six months imprisonment suspended for two years and both were ordered to pay $\$ 2000$ costs to the Attorney-General's Office (Fiji Times, 21 February 2013).

The pressure on local media had created a repressive environment and before arriving in the country, Ghai stated that the Fiji regime should review 
all laws that restrict freedoms in Fiji to ensure frank discussions around the constitution before the process began (RNZI, 13 March 2012). He said Fiji's laws should be restored to a state compatible with the guarantees of the Bill of Rights under Fiji's 1997 constitution and the role of the military must be addressed (ibid). However, after the commencement of the constitution consultation process, Bainimarama rejected Ghai's calls for greater freedom in Fiji, saying the Kenyan did not properly understand the situation in the country (ABC News, 16 August 2012). 'The comments by the chair are unfortunately misplaced... none of the laws currently in place stop any Fijian or hinder any Fijian from making any submission to the commission on any topic,' he told Fijivillage (16 August 2012).

\section{Decrees governing constitutional process}

While repressive laws continued to exist, four Fiji constitutional process decrees were promulgated to enable the creation of the constitution. The first was the Constitutional Commission Decree 2012 (Fiji Government, 18 July 2012) which sets out the powers and guidelines for operations of the Constitution Commission. Notably, it specifies some non-negotiable principles such as equal citizenry, secular state, removal of corruption, one person one vote, and elimination of ethnic voting. The commission has powers to enter contracts, commission research, use advice of experts, employ staff and consultants, and also to hold (only for good reason) meetings and hearings in private. Its functions include to 'prepare a draft constitution and any consequential changes to existing laws as may be necessary'. The decree emphasises that the constitution must make provisions for immunity and carry forward the immunities provided in various decrees after the 1987 and 2006 coups to the disciplined forces and others mentioned. The decree grants independence to the commission, provides immunities to those making submissions (within the law), and provides for suspension of Section 8 of the Public Order Act to allow for meetings to take place without a permit.

While the non-negotiable principles and requirement for immunity for coup-makers in the draft constitution provided limitations to the commission's work, the immunities for submission makers and relaxation of the Public Order Act were seen as an encouragement for all people to give submissions on any issue without fear of reprisal. The second was the Constituent Assembly and Adoption of Constitution Decree 2012 (Fiji government, 18 July 2012) which 
provides the powers, processes, guidelines, timeframes and framework for the work of the Constituent Assembly and subsequent adoption of the new constitution. The above two decrees were amended once and will be referred to later.

Ghai and the commissioners encouraged people to freely make submissions on any issue in any medium. To encourage people to make submissions, the decree authorises the presentation of submissions in the language they are comfortable with, Ghai said, and those whose hearing were impaired were entitled to use sign language. 'The decree also grants all those who make written or oral submissions immunity from civil or criminal proceedings for any evidence or information given to the commission,' Ghai added (Fiji Times, 11 August 2012). A week later, Ghai said:

This is a free process... The Constitution Commission is an independent body and is here to listen to the people of Fiji. This is the process where we encourage people of all ethnicity, class and community to come forward and make their views known to us... This is why we are here- to listen to the people. (Fiji Times, 18 August 2012)

Ghai had earlier stated that the government should not scrutinise or criticise submissions made by people in the constitution consultation process (ibid). However, Bainimarama continued to attempt to control the work of the commission. In August 2012, while denying that the laws in Fiji could stop anyone from making submissions, Bainimarama warned Ghai to '... concentrate on his job and not get involved in politics' - remarks labelled as 'heavy-handed and threatening' by former Opposition leader Mick Beddoes (ABC News, 22 August 2012). Beddoes observed that Bainimarama had '... taken it upon himself to make comments on what some of the people are submitting' (ibid).

Former Prime Minister Laisenia Qarase's comments for constitutional changes to proceed under an elected government, got a reply from the AttorneyGeneral, who was at the time also acting Prime Minister that, 'some politicians were looking backward, caught in a time warp where nepotism, elitism and racism were the norm' and that 'there were voices that echoed from that past, for those who sought to regain power and take Fiji back to the dark ages'. Sayed-Khaiyum added, 'The Bainimarama government breaks away from the petty politics of the past in which personalities took precedence over building a modern and inclusive Fiji' (Fiji Times, 12 March 2012). Since the 2006 
military takeover, Bainimarama and key regime stakeholders have many times stated in the media that Qarase will not return to power; such statements and statements against Qarase's Soqosoqo Duavata ni Lewenivanua Party and the Fiji Labour Party were repeated during the constitutional process.

While denying that the laws in Fiji could stop anyone from making submissions, Bainimarama threatened politicians, NGOs and the commission itself. In August 2012, three women's NGOs requested these concerns be addressed: the non-negotiable principles, the requirement for immunity for the 2006 coup-makers in the new constitution, the legitimacy of the process, and an environment that restricted full participation and reporting (Scoop Media, 10 August 2012). Bainimarama's reply to the female heads of these NGOs was that NGOs and others which did not contribute positively to a better Fiji for all citizens were not important and that the Constituent Assembly would be made up of credible people who thought positively about Fiji's future (Fijivillage, 14 August 2012).

Although the decree provided the Constitution Commission powers to enter contracts and employ consultants, the short-term hiring of Fiji's former Vice-President, former judge and Bau High Chief Ratu Joni Madraiwiwi was attacked by Bainimarama because Ratu Joni had also been part of a delegation that made a submission for Fiji to be declared a Christian state (FBC News, 5 November 2012). Ghai defended the impartiality of the constitution process, and admitted there was 'massive interference' by the regime with the PM harassing him with emails to do this or not to do that (Radio Australia, 6 November 2012). Ghai was concerned that the commission's powers to examine existing laws for possible incompatibility with the draft constitution had been removed.

There are hundreds of decrees passed since the coup which have stripped the rights of access to courts, the media is under pressure, subject to heavy penalties, trade union rights have basically been removed, civil servants have no protection... I do not see how Fiji is going to have a free and fair election unless these decrees are cleaned up. (ibid.)

The references by the regime that Ghai was sympathetic to anti-regime views appeared ironic in light of revelations that Attorney-General Sayed-Khaiyum and Chief Justice Anthony Gates were former students of his (RNZI, 13 March 2012). The three local members of the Constitution Commission: 
Dr Satendra Nandan, Peni Moore and Taufa Vakatale had been supportive of the regime. Therefore, despite the fact that there were already three commissioners supportive of the regime, the government did not want one person with seemingly anti-government views to be a consultant of the commission. It promulgated an amendment (Fiji Government, 31 October 2012) to the Constitution Commission decree under which the commission was required to publish in the newspaper each month a financial report of its expenditure; and a list of its employees (including consultants) and its salaries (including benefits). This and a further requirement for immediate publication of the expenditure from June to October 2012, was perceived as another attempt to restrict the freedom of the commission and intimidate its employees.

\section{Types of views expressed in submissions}

The Constitution Commission visited 97 venues to receive oral submissions and received 1708 written submissions, 319 electronic submissions and 15 photographic submissions (Constitution Commission website). Many contrasting views were expressed in submissions. While many wanted a secular state, some also wanted a Christian state. There was a call for a common name for people from Fiji with equal rights for all ethnic groups. However, some still felt that the iTaukei (Indigenous Fijians) should have a special reserved place.

People from all walks of life expressed concern about Fiji's coup culture and called for an end to it as well as increased penalties for those participating in coups and treasonous activities. There were calls for a return of the military to the barracks, the need for the military to be subservient to the government and the will of the people, and downsizing of Fiji's military to make it less threatening to democracy and appropriate to Fiji's small size. People strongly expressed that they did not want immunity for the perpetrators and beneficiaries of the 2006 coup and some felt such an immunity should not be part of the new constitution as it would encourage future coups in Fiji.

There was a call for the revival of the Great Council of Chiefs. There were strong calls for democracy and human rights to be guaranteed including the right to choose leaders through free and fair elections and freedom of opinion and expression in a free press.

People saw hope in Ghai and used the submission process as an opportunity to air their grievances on everyday issues such as: access to land, poor 
health care, lack of medication, poor wages, bad roads, welfare payments, infrastructure problems and housing. Members of the Fiji Mineworkers Union, who have been on strike since 1991, also made a submission to the commission and called for human rights, an independent judiciary, and the rights of workers and trades unions to be guaranteed.

Ghai encouraged the military to come to the middle point and engage in the constitution-making process and the Commission organised seminars to educate people on issues such as the concept of a secular state and how a transition could be made from a military government to a civilian government. Retired Indonesian general Agus Widjojo spoke on the Indonesian experience of transition from military to democratic rule at the seminar 'Democratic Transition: Comparative experience' held at the Fiji National University (Fiji Times, 20 October 2012). The Fiji military did not send a representative to speak at this seminar. In his opening address, Ghai said the dislike for coups was one uniting factor of the Fijians. 'People from rural communities, urban centres, different communities, different parts of Fiji have urged us to find the magical formula which makes coups impossible in Fiji...now that is a challenge,' he said. Ghai believed that 'having very concrete policies ... and creating political institutions which are democratic, which involves people in public affairs where people feel a responsibility for their own lives and are willing to defend the system that gives them these opportunities could help end coups in Fiji' (Constitution Commission website). Prior to the commencement of the commission's work, the Republic of Fiji Military Forces (RFMF) Land Force Commander Colonel Mosese Tikoitoga said the RFMF would make its own submission as per its role and the way Fiji should go forward from 2014 (Fijilive, 24 June 2012). The RFMF still had not made its submission when the commission stopped taking submissions in October 2012. Finally, in December 2012, the RFMF made its submission with a key recommendation for adoption of current immunity provisions to the disciplined forces in the new constitution (Fijilive, 22 December 2012).

Therefore, while participation in the constitution process was received from all sides, the military and the government - the two key institutions responsible for implementation of coups in Fiji-refused to participate and engage; they watched and communicated from the sidelines. This meant that instead of bargaining and negotiating for a solution to the coup culture, they imposed non-negotiable conditions and ultimatums. 


\section{Were media self-censoring while reporting the submission process?}

The decrees on the constitutional process provided immunity to those making submissions and also to the media organisations reporting the submissions. This meant the media felt free to report the process. There is clear evidence that self-censorship was present in Fiji at least since the imposition of the Media Decree. However, there is no clear evidence that self-censorship occurred during the constitution consultation process. The immunities under the decree plus the assurances by the commission chair provided confidence among people to express themselves. This meant the media reported more freely on views opposed to the military regime, shown in the reporting of a wide range of submissions calling for the prosecution of coup-makers and harsh penalties for treason. Submissions opposed to the regime by ordinary citizens, former prominent people, political parties, villagers, workers, NGOs, children, trade unions, religious and civil society organisations were covered freely by the media, albeit not in their old style of 'inflammatory' journalism.

This temporary freedom provided a breath of fresh air to the people of Fiji who were starved of expressing these views since the enforcement of the repressive laws after the April 2009 events. Most of the political interactions reported in the media were not occurring from April 2009 to mid-2012. People starved of freedom of expression found a window to air grievances and a wide range of viewpoints from all walks of life were expressed.

People of Fiji showed faith in Professor Yash Ghai and placed hope for their country's future in the constitution they expected to be created under his benevolent guidance. But many ordinary citizens still refrained from airing their views, including civil servants, those working for government-funded organisations, business organisations and middle-class professionals who feared for their job security and safety. Some people may have felt deterred because of the presence of plainclothes policemen who were seen taking notes during the submission process, which was viewed as intimidating by Ghai and some women's NGOs (RNZI, 7 September 2012). It was disappointing that six years after the coup, new political actors had not eventuated. People still felt the freedoms were temporary and the military would probably not give back power to an elected government in 2014. If restrictive legislations had been removed, it may have encouraged the above silent groups to also express their views. 
At a Media and Democracy Conference held at the University of the South Pacific in September 2012, Communications Fiji Ltd (FijiVillage) journalist Vijay Narayan strongly defended his company's news and denied any selfcensorship (Pacific Media Watch, 12 September 2012). However, Fiji One Television legal manager Tanya Waqanika confirmed that they had had their 'fair share of detention, fair share of threats' and operated under censorship by consulting with the Ministry of Information and obtaining prior permission for a story to avoid any backlash (ibid.). She confirmed that journalists were afraid to ask questions for fear of the harsh penalties and because of the example of the court case against The Fiji Times. Fiji Sun deputy editor Josua Tuwere acknowledged censorship and claimed it had been a good thing for them, 'It made us better journalists - we were forced to think about the repercussions of what we write' (ibid.). Journalism educator David Robie's Café Pacific blog (9 September 2012) observed that censorship by the media was evident in the manner in which negative views on Fiji's media by the Permanent Secretary for Information, Sharon Smith-Johns, and USP Deputy Vice-Chancellor Dr Esther Williams had been widely published in the dailies, whereas key presentations by media experts Professor Robert Hackett and others were not reported.

I personally feel the effects of self-censorship by the media when letters to the editor by many locals on important issues that were published in the past now never get published. However, I do not believe that self-censorship and restraint by citizens has encouraged the regime to come to the middle ground, because instead of fostering peace, it has led to the creation of harsher new decrees by the regime to restrict participation and reporting in the upcoming elections.

\section{Reactions of authorities to submissions}

The commission kept offering olive branches to the military and Bainimarama's requesting the military become part of the discussions, however, the regime refused to come to the middle ground. Instead of allowing the Constituent Assembly and Fiji's people an opportunity to look at the Ghai Draft, Bainimarama criticised the draft constitution saying it 'proposes to force the military out of political life and make it permissible for soldiers to disobey an order to take part in a coup' and claiming it could lead 'to financial and economic catastrophe and ruin' (Stuff, 10 January 2013). On 22 December 
2012, 600 copies of the draft constitution were seized from the printers by the police and the final proof copy shredded and burnt in Ghai's presence (Radio Australia, 28 December 2012). Ghai was personally abused by the officers and said he felt extremely sorry for the people of Fiji:

If this was indeed an order from the government then it shows such contempt for our work, and in turn contempt for the people who had come out in their thousands and thousands to give us their views, participate in the process. And I felt really not just a betrayal, I just felt 'Will Fiji ever have a democratic constitution?' (ibid.)

Immediately, an amendment (Fiji government, 24 December 2012) to the Constituent Assembly and Adoption of Constitution Decree was promulgated to give powers for the appointment of chair and co-chair of the Assembly to the Prime Minister. Fiji's President, Ratu Epeli Nailatikau, criticised the Ghai Draft, labelling it elitist and which had 'succumbed to the whims of the few who have an interest in perpetuating divisions within our society. A Constitution cannot be drafted simply with the view to negotiate between different political interests. It would appear that the Ghai Draft ... was prepared to be seen as an appeasement' (Fiji Times, 10 January 2013). Other things criticised by Nailatikau was the recommendation for a 144-member Constituent Assembly, undoing some financial projects, having a transitional cabinet, and requiring 'an oversized bureaucratic structure' (ibid). Nailatikau used these justifications in his speech to 'request' the PM to prepare a new draft constitution.

Many of the above critical views were not allowed to be published between April 2010-June 2012. This means that two-and-half years of repression through censorship did not change people's feelings and attitudes about the coup, it only temporarily prevented the airing of views in public. In the last week, buoyed by the Ghai team's encouragement and inspired by preceding submissions, citizens rushed to give views and the final two days were reserved for submissions by appointment. A few, notably the young women from the Fiji Women's Rights Movement (FWRM) Emerging Leaders' Forum Alumni, were extremely disappointed (Fiji Times, 19 October 2012) as they were unable to get an appointment for an oral submission because the days were fully booked.

While the submission process was being freely reported on by the media, 
I believe self-censoring was still occurring. This is evident in the manner in which confrontational issues were being reported. Whenever views were expressed which did not agree with the regime, the regime actors would issue stern intimidating statements such as those against politicians, Ghai and NGOs, including the launch of a contempt of court case against the democracy and human rights group Citizens' Constitutional Forum for publishing an article in its newsletter titled 'Fiji-The Rule of Law Lost' (Fijivillage/Pacific Media Centre, 1 December 2012). The media would report intimidating statements, however, replies to these statements were not given the same importance and the conversations in the media tended to end with the regime having the final word. This is not in line with peace journalism which requires all sides of views to be equally reported for a solution to be found. Therefore, self-censorship by the media, while appearing to foster peace, stopped conversations and has not been able to achieve the goal of peace journalism to find solutions to conflict.

The draft constitution was a fairly good outcome. However, the regime was not sincere about its promises and scrapped the Ghai draft. Fiji's media, although proclaiming they are not engaging in self-censorship, did not report the burning of the draft constitution by the police until after the regime was compelled to defend its actions after Radio Australia (28 December 2012) revealed the incident through an interview with Professor Ghai. Similarly, reporting of a video that went viral on YouTube (www.youtube.com/ watch?\&v=GgdrQ0j-rSI) and anti-regime blogs of two handcuffed men being brutally beaten were reported in the Australian and New Zealand media on 5 March 2013. Fijivillage and The Fiji Times reported the news a day later whereas Fijilive and Fiji One news reported the incident around 6pm on 5 March after a press statement by police. In normal times, Fiji's daily media would have reported this incident well before their Australian and New Zealand counterparts.

The lack of criticism in the local media of the disrespectful treatment of Ghai by the police is also a concern. Either people stopped commenting on such incidents because they had lost faith that their statements would have any impact on the regime, or maybe the media was self-censoring. Whatever the reason, it reflects the severe impact of repressive laws on Fiji's society-that people and the media have stopped commenting and criticising the wrongness of some government actions.

The Bainimarama government did not release the draft constitution 
prepared by the Ghai-led commission. Instead, the regime had the draft changed to reflect its own agenda. This shows a breach of faith and transparency by the regime. A draft constitution claiming to be the one by the Ghai team surfaced on the web and Commissioner Moore confirmed that it was a copy of the first draft of the constitution they had prepared but not the final draft (Fijilive, 28 December 2012).

\section{Has self-censorship promoted peace?}

Some critics of the Fiji media's style of reporting have blamed it for inflaming ethnic tensions in the lead-up to the coups of 1987 and 2000. However, in the aftermath of the December 2006 military coup, journalism educator Shailendra Singh observed that Fiji media had played the role of an opposition in the absence of a Parliament (Fijilive, 1 December 2008). According to James Bhagwan, this led to conflict between the news media and the interim government (Bhagwan, 2011, p. 282). Bhagwan observed that the news media were originally propaganda-oriented in coverage of military statements but increasingly shifted to being truth-oriented by exposing untruths of both sides, allowing them to retain credibility, yet bringing them into conflict with the military regime (p. 288). Singh, Bhagwan and others have found that the type of journalism practised in Fiji in the past could be likened to "war journalism' which had fuelled the fires of racism and aided fuelling emotions which culminated in the past coups. This has been used to justify the need for greater regulation of Fiji's media. However, it cannot be used to justify the draconian media decree.

Censorship of the media after the 2009 abrogation of the 1997 constitution has led to the voice of opposition in Fiji being virtually silenced and the voiceless becoming invisible. This has created a false depiction of calm. Forced censorship after the 2009 events and self-censorship after the 2010 Media Decree have not achieved the goals of peace because the conflict has become hidden because of censorship and avenues to resolve it cannot be explored. Censorship has promoted unchallenged publication of false propaganda. Untruths on all sides cannot be exposed and names of all evildoers cannot be revealed because the regime would punish the media under the new decree. Conflict resolution processes through constitution-making are not being given a fair chance because of repression.

Forced and voluntary censorship has created the 'emperor's new clothes' 
syndrome in Fiji. Those familiar with this children's story book are aware that in this fable people saw that the emperor was naked but fearing the consequences of saying that to the emperor, they pretended they could see the new clothes the emperor was wearing. In the same way, some people in Fiji, while knowing that the regime is doing wrong, on record praise or agree with the regime for fear of retaliation by the military government.

\section{Concluding remarks}

In conclusion, through observation and analysis of the Fiji media reporting of the constitution review process, I can say that the media, prompted by the reassurances provided through immunities under decrees, reported freely on the constitution submission process only. This did not encourage everyone to air their views and a key group of people in Fiji remained 'silent'. It is unclear whether the media will report freely in the aftermath of the submission process as new decrees put further pressure on the media to avoid reporting on political parties. Media in Fiji now are not entirely focused on reporting inflammatory speeches by political actors. However, censorship has led to an over-reporting of government-oriented stories. Threatening and intimidating speeches by Bainimarama and the regime dominate headlines. By contrast, the response to such speeches are given negligible space. The refusal of the government side to engage in the constitution process and the inability of the media to report fully on the sides opposed to the regime mean that instead of finding a solution, the conflict in Fiji is becoming further entrenched. The conflict of the coup-created regime is being perpetuated through the regime's freedom to spread its propaganda without much criticism or challenge. Therefore, while censorship may have fostered an increased reporting of peace-oriented stories in Fiji, it cannot aid in finding a peaceful solution until the regime allows the media full freedom to report on all sides of the story. 


\section{References}

Bhagwan, J. (2011). Making a case for peace journalism in Fiji. The Journal of Pacific Studies, 31(2), 277-292.

Bhim, M. (2011). Stifling opposition: An analysis of the approach of the Fiji government after the 2006 coup. SSGM Discussion Paper, Australian National University. Retrieved on March 11, 2013, from http://ips.cap.anu.edu.au/ssgm/papers/discussion_papers/2011_06_bhim.pdf

Constitution Commission-Fiji. How to stop coups in Fiji [Media statement]. Retrieved on February 28, 2013, from www.constitution.org.fj/index.php?option=com_co ntent\&view $=$ article \&id=108\%3Ahow-to-stop-wars-in-fiji\&catid=5\%3Apressroom\&Itemid=1

Constitution Commission-Fiji. View Submissions. Retrieved on February 27, 2013, from www.constitution.org.fj/index.php?option $=$ com phocadownload\&view $=$ se ction\&id $=4 \&$ Itemid $=43$

Cooney, C. (2012, November 6). Ghai defends impartiality of constitutional process. Radio Australia. Retrieved on February 26, 2013, from www.radioaustralia.net. au/international/radio/program/pacific-beat/ghai-defends-impartiality-of-constitutional-process/1041792

Elbourne, F. (2012, March 12).Poll first: Qarase. The Fiji Times. Retrieved on February 26, 2013, from www.fijitimes.com/story.aspx?id=195787

Field, M. (2013, January 10). Fiji dictator burns draft constitution. Stuff. Retrieved on March 1, 2013, from www.stuff.co.nz/world/south-pacific/8163841/Fiji-dictatorburns-draft-constitution

Fiji Constitution plan unveiled. (2009, July 1). BBC News. Retrieved on January 29, 2013, from http://news.bbc.co.uk/2/hi/asia-pacific/8128211.stm

Fiji Government. (2012, July 18). Fiji constitutional process (Constitution Commission) Decree 2012. Suva: Government of Fiji Gazette, Government Printer.

Fiji Government. (2012, July 18). Fiji constitutional process (Constituent Assembly and Adoption of Constitution) Decree 2012 . Suva: Government of Fiji Gazette, Government Printer.

Fiji Government. (2012, October 31). Fiji constitutional process (Constitution Commission) (Amendment) Decree 2012. Suva: Government of Fiji Gazette, Government Printer.

Fiji Government. (2012, December 24). Fiji constitutional process (Constituent Assembly and Adoption of Constitution) (Amendment) Decree 2012. Suva: Government of Fiji Gazette, Government Printer.

Fiji media 'playing opposition role'. (2008, December 1). Fijilive. Retrieved on March 5, 2013, from www.fijilive.com/news/2008/12/fiji-media-playing-opposition-role/11195.Fijilive

Fiji: NGOs concerned about constitution-making process. (2012, August 10). [Press Release]. Scoop Media. Retrieved on February 26, 2013, from www.scoop.co.nz/ stories/WO1208/S00202/fiji-ngos-concerned-about-constitution-making-process. htm 
Fiji PM criticised over constitution comments. (2012, August 22). ABC News. Retrieved on January 31, 2013, from www.abc.net.au/news/2012-08-21/an-fijiopposition-polly-slams-pm-over-constitution/4213758

Fiji: Self-censorship claims and denials fuel media debate. (2012, September 12). Pacific Media Watch. Retrieved on March 1, 2013, from www.pmc.aut.ac.nz/pacific-media-watch/fiji-self-censorship-claims-and-denials-fuel-media-debate-8103

Fiji's Bainimarama criticises constitution appointee. (2012, August 16). ABC News. Retrieved on January 25, 2013, from www.abc.net.au/news/2012-08-16/an-fijibainimarama-ghai/4203912

Fiji's Ministry of Information. (2013, January 10). The President Ratu Epeli Nailatikau's address on Fiji's constitution and constituent assembly. The Fiji Times. Retrieved on March 1, 2013, from www.fijitimes.com/story.aspx?id=222129

Gonedua, M. (2012, December 22). Immunity is nothing new: RFMF. Fijilive. Retrieved on January 31, 2013, from http://fijilive.com/news/2012/12/immunityis-nothing-new-rfmf/50120.Fijilive

Gonedua, M. (2012, December 28). Online copy not the final draft: Moore. Fijilive. Retrieved on March 1, 2013, from www.fijilive.com/news/2012/12/online-copynot-the-final-draft-moore/50284.Fijilive

Gonedua, M. (2012, June 24). We will also make submissions: Army. Fijilive. Retrieved on January 31, 2013, from www.fijilive.com/news/2012/06/we-willalso-make-submissions-army $/ 44820 /$ videos.Fijilive $? i d=28$

Head of Fiji Constitution Commission concerned about intimidation. (2012, September 7). Radio New Zealand International. Pacific Islands Report. Retrieved on March 6, 2013, from http://archives.pireport.org/archive/2012/september/09-10-16.htm

Hill, B. (2012, December 28). Fiji draft constitution seized by police, some copies burnt. Radio Australia. Retrieved on March 1, 2013, from, www.radioaustralia. net.au/international/radio/program/pacific-beat/fiji-draft-constitution-seized-bypolice-some-copies-burnt/1067186

Loanakadavu, N. (2012, August 11). Decree encourages submissions. The Fiji Times. Retrieved on January 25, 2013, from www.fijitimes.com/story.aspx?id=208860

Loanakadavu, N. (2012, August 18). Ghai: It's a transparent process. The Fiji Times. Retrieved on January 31, 2013, from www.fijitimes.com/story.aspx?id=209426

Loanakadavu, N. (2012, October 20). Fiji on path to transition. The Fiji Times. Retrieved on February 28, 2013, from www.fijitimes.com/story.aspx?id=214991

Loanakadavu, N. (2012, October 19). NGO queries 'denial'. The Fiji Times. Retrieved on March 5, 2013, from http://www.fijitimes.com/story.aspx?id=214894

Loanakadavu, N. (2013, February 21). Times fined \$300,000. The Fiji Times. Retrieved on February 22, 2013, from http://www.fijitimes.com/story.aspx?id=225792

Loga, M. (2012, November 5). Commission stands by Ratu Joni. FBC News. Retrieved on February 26, 2013, from www.fbc.com.fj/fiji/5836/commissionstands-by-ratu-joni

McGoon, G., and Narayan, V. (2012, August 14). NGOs who [sic] do not contribute positively are not important-PM. Fijivillage. Retrieved on September 2, 2012, 


\section{MEDIA AND DEMOCRACY IN THE PACIFIC}

from www.fijivillage.com/?mod=archivedstory\&id $=1308124999 \mathrm{~d} 728568 \mathrm{c} 080 \mathrm{~b}$ f3adbdf1

Naleba, M. (2012, November 27).Times awaits fate. The Fiji Times. Retrieved on January 24, 2013, from www.fijitimes.com/story.aspx?id=218359

Narayan, V. (2012, August 16). There are no restrictions, do your job-PM. Fijivillage. Retrieved on September 2, 2012, from www.fijivillage.com/?mod=archived story\&id=1608126c6938be103f17ebe0535482

Narayan, V., Rainima, T. (2012, December 1). Fiji: AG office calls for guilty verdict in CCF contempt case. Fijivillage/Pacific Media Watch. Retrieved on March 7, 2012, from www.pmc.aut.ac.nz/pacific-media-watch/fiji-ag-office-calls-guiltyverdict-ccf-contempt-case- 8162

Nasiko, R. (2011, April 14). Mau gets 9 months, Patel 12 months. Fijilive. Retrieved on July 25, 2011, from www.fijilive.com/news/2011/04/14/32216.Fijilive

Nawaikama, S. (2009, January 27). Deported. The Fiji Times. Retrieved on January 23, 2013, from www.fijitimes.com/story.aspx?id=112887

Robie, D. (2012, September 9). Media, democracy and self-censorship in the Pacific. Café Pacific. Retrieved on March 1, 2013, from http://cafepacific.blogspot. com/2012/09/media-democracy-and-self-censorship-in.html

Round, S. (2012, March 13). Yash Ghai speaks on Fiji constitution plan. Radio New Zealand International. Retrieved on January 24, 2013, from www.rnzi.com/pages/ news.php?op=read\&id $=66782$

Simpson, S. (2010, November 13). FIJI: Deputy editor Foster resigns from Fiji Times. Fiji Broadcasting Corporation/Pacific Media Watch. Retrieved on January 23, 2013, from www.pmc.aut.ac.nz/pacific-media-watch/2010-11-13/fiji-deputyeditor-foster-resigns-fiji-times

Staff writers. (2010, September 15) News Limited sells Fiji Times to Fijian company Motibhai. The Australian. Retrieved on January 29, 2013, from www.theaustralian.com.au/news/world/news-limited-sells-fiji-times-to-fijian-company-motibhai/ story-e6frg6so-1225924003166

Mosmi Bhim is a lecturer at the Fiji National University and a former journalist. This article is based on a presentation made at the Media and Democracy in the South Pacific Conference, University of the South Pacific (USP), 5-6 September 2012. The views expressed in this article are her own and not of the FNU.

Mosmi_Bhim@hotmail.com 